\title{
GAMBARAN PROGRAM KOTAKU ( KOTA TANPA KUMUH ) KOTA SEMARANG TAHUN 2019 (STUDI EVALUASI KEBIJAKAN)
}

\author{
Suharto \\ Dosen Ilmu Politik, Fakultas Imu Sosial dan Ilmu Politik \\ Universitas Wahid Hasyim (UNWAHAS) \\ Jl. Menoreh Tengah X No.22 Sampangan, Semarang-50236 \\ Email: hartoss@gmail.com
}

\begin{abstract}
Management of housing and slum settlements is carried out in various forms of service and facilitation as follows: (1) fulfillment of decent and affordable housing needs through housing loans / subsidized housing loans and self-help housing development; (2) improving the quality of the settlement environment through the assistance of basic housing infrastructure and facilities, providing clean water facilities in water-prone settlements, structuring and rehabilitating slum settlements, empowering communities in the framework of strengthening economic capacity and improving social life; (3) institutionalizing a system for implementing housing and settlement development by involving the community as the main actor.

Given the limited capacity of the government through the APBN and $A P B D$ in handling housing and slum settlements, the government took the decision to carry out handling of housing and slum settlements through the City Without Slum Program (KOTAKU).

The implementation of the Tridaya approach in the KOTAKU program city of Semarang includes: (1) empowering local governments and communities through capacity building in the form of training and mentoring; (2) utilization of environmental facilities by improving the quality of the settlement environment through the procurement and repair of primary basic infrastructure and facilities as well as repair of unsuitable houses; and (3) community economic empowerment which is carried out through channeling with other programs in the field of Public Works and various activities carried out in the regions. To get a comprehensive picture of the program, researchers need to evaluate the policies of the Semarang City KOTAKU (City Without Slums) program in 2019.
\end{abstract}

Keywords: KOTAKU (City Without Slums), Government Capacity, Policy Evaluation. 


\section{A. PENDAHULUAN}

Cepatnya laju urbanisasi yang tidak dibarengi dengan ketersediaan ruang, prasarana dan sarana serta utilitas yang cukup menyebabkan suatu kawasan permukiman over capacity dan menjadi kumuh. Pada umumnya kondisi permukiman kumuh menghadapi berbagai permasalahan, antara lain : (1) luas bangunan yang sangat sempit dengan kondisi yang tidak memenuhi standar kesehatan dan kehidupan sosial, (2) kondisi bangunan rumah yang saling berhimpitan sehingga rentan terhadap bahaya kebakaran, (3) kurangnya air bersih, (4) jaringan listrik yang ruwet dan tidak mencukupi, (5) drainase yang sangat buruk, (6) jalan lingkungan yang sempit dan buruk, (7) ketersediaan sarana MCK yang sangat terbatas. Kondisi dan permasalahan tersebut telah berdampak pada timbulnya berbagai jenis penyakit, menurunnya produktivitas warga penghuni, timbulnya kerawanan dan penyakit sosial.

Akibat tingginya laju urbanisasi ini dapat dikatakan bahwa secara umum kota-kota terutama kota besar di Indonesia memiliki permasalahan yang kompleks menyangkut permukiman kumuh serta menanggung beban yang berat terutama dalam memenuhi kebutuhan perumahan warganya yang sebagian besar adalah kelompok MBR (Masyarakat Berpenghasilan Rendah). Kemampuan pemerintah untuk menangani perumahan dan permukiman kumuh melalui APBN sangatlah terbatas. Secara keseluruhan area permukiman kumuh yang mampu ditangani oleh pemerintah melalui APBN dan APBD sampai tahun 2004 hanya seluas 2.875 ha, dibandingkan dengan luas keseluruhan area permukiman kumuh seluas 47.393 maka masih terdapat 44.250 ha area permukiman kumuh yang belum tertangani. Sehingga untuk mewujudkan Cities without slums pada tahun 2015 Pemerintah Indonesia harus mampu menangani area permukiman kumuh seluas 4.7393 ha/tahun dan di samping itu harus dilaksanakan upaya pencegahan terhadap semakin berkembang dan meluasnya area permukiman kumuh. 
Jurnal SOSIO DIALEKTIKA 6 (1) (2021)

P-ISSN: 2540.8941 e-ISSN: 2623.2944

sosiodialektika@unwahas.ac.id
Gambaran Program Kotaku

(Kota Tanpa Kumuh )

Kota Semarang Tahun 2019

(Studi Evaluasi Kebijakan)

Undang-undang (UU) No. 1 Tahun 2011 tentang Perumahan dan Kawasan Permukiman mengamanatkan bahwa penyelenggaraan atas perumahan dan kawasan permukiman termasuk pencegahan kumuh dan peningkatan kualitas permukiman kumuh wajib dilakukan oleh Pemerintah, Pemerintah Daerah, dan/atau setiap orang. Mengingat kemampuan pemerintah secara rutin melalui APBN dan APBD yang sangat terbatas dalam penanganan perumahan dan permukiman kumuh, maka pemerintah mengambil keputusan untuk melaksanakan penanganan perumahan dan permukiman kumuh melalui Program Kota Tanpa Kumuh (KOTAKU).

Pelaksanaan pendekatan Tridaya dalam KOTAKU meliputi : (1) pemberdayaan pemerintah daerah dan masyarakat melalui pengembangan kapasitas dalam bentuk pelatihan dan pendampingan; (2) pendayagunaan fasilitas lingkungan dengan peningkatan kualitas lingkungan permukiman melalui pengadaan dan perbaikan prasarana dan sarana dasar primer serta perbaikan rumah tidak layak; dan (3) pemberdayaan ekonomi masyarakat yang dilaksanakan melalui chanelling dengan program lain di bidang Pekerjaan Umum dan berbagai kegiatan yang dilaksanakan di daerah. Untuk mendapatkan gambaran yang menyeluruh dari program tersebut, maka peneliti perlu mengevaluasi kebijakan program KOTAKU (Kota Tanpa Kumuh) Kota Semarang tahun 2019. Adapun permasalahan dalam penelitian ini, bagaimana gambaran pogram KOTAKU (Kota Tanpa Kumuh) Kota Semarang Tahun 2019 (Studi Evaluasi Kebijakan) ? Penelitian ini bertujuan : Untuk mengetahui gambaran pogram KOTAKU (Kota Tanpa Kumuh) Kota Semarang Tahun 2019 (Studi Evaluasi Kebijakan).

Penelitian tentang evaluasi kebijakan program KOTAKU (Kota Tanpa Kumuh) ini merupakan penelitian tentang program pemerintah (Pusat / Daerah) yang terkait program dengan pendekatan pemberdayaan masyarakat. Program KOTAKU ini merupakan tindak lanjut dari program P2KP yang dahulu merupakan salah program untuk menanggulangi kemiskinan akibat dampak krisis ekonomi pada tahun 1999. Dalam 
perkembangannya program ini berubah nama menjadi PNPM P2KP yang lebih focus pada pogram pemberdayaan masyarakat. Dan sebelm berubah nama menjadi program KOTAKU, program yang focus pada kemiskinan perkotaan ini bernama program PNPM Mandiri Perkotaan. Maka ntk mengetahui gambaran yang jelas dari program KOTAKU dengan program sebelumnya perlu kita mengevaluasi kebijakan tersebut.

Menurut Woll (1966) mengartikan kebijakan publik adalah " sejumlah aktivitas pemerintah untuk memecahkan masalah dimasyarakat, baik secara langsung maupun melalui berbagai lembaga yang mempengaruhi kehidupan masyarakat. Konsep kebijakan publik yang diberikan oleh Anderson (1979 : 46), yaitu "Public Policies are those policies developed by governmental bodies and officials". (“Kebijakan publik adalah kebijakan-kebijakan yang dikembangkan oleh badan-badan dan pejabat-pejabat pemerintah").

Jadi kebijakan publik timbul melalui serangkaian proses. Artinya, kebijakan publik tidak timbul secara mendadak, melainkan melalui suatu proses tertentu yang berkaitan dengan tujuan-tujuan kebijakan. Proses yang dilalui oleh kebijakan publik merupakan suatu rangkaian yang saling berkaitan, yang setiap tahap dalam rangkaian prosesnya akan mempengaruhi tahap-tahap lainnya. Proses kebijakan publik melewati empat rangkaian tahap tindakan pemerintah.

(1) Pertama, tahap persepsi/definisi agregasi, organisasi, representasi, dan penyusunan agenda, yang merupakan tindakan membawa permasalahan pada pemerintah.

(2) Kedua, tahap formulasi, legitimasi, dan penganggaran, yang pada dasarnya merupakan suatu tindakan langsung pemerintah untuk mengembangkan dan mendanakan sebuah program.

(3) Ketiga, tahap implementasi atau pelaksanaan, adalah sebagai tindakan pemerintah untuk kembali pada permasalahan.

(4) Keempat, tahap evaluasi dan penyesuaian/ terminasi, yang pada dasarnya adalah kembalinya program kepada pemerintah untuk 
Jurnal SOSIO DIALEKTIKA 6 (1) (2021)

P-ISSN: 2540.8941 e-ISSN: 2623.2944

sosiodialektika@unwahas.ac.id
Gambaran Program Kotaku

(Kota Tanpa Kumuh )

Kota Semarang Tahun 2019

(Studi Evaluasi Kebijakan)

dilakukan peninjauan kembali atau perubahan-perubahan bilamana diperlukan.

\section{Bagan : Tahapan Kebijakan Publik dalam Good Governance}

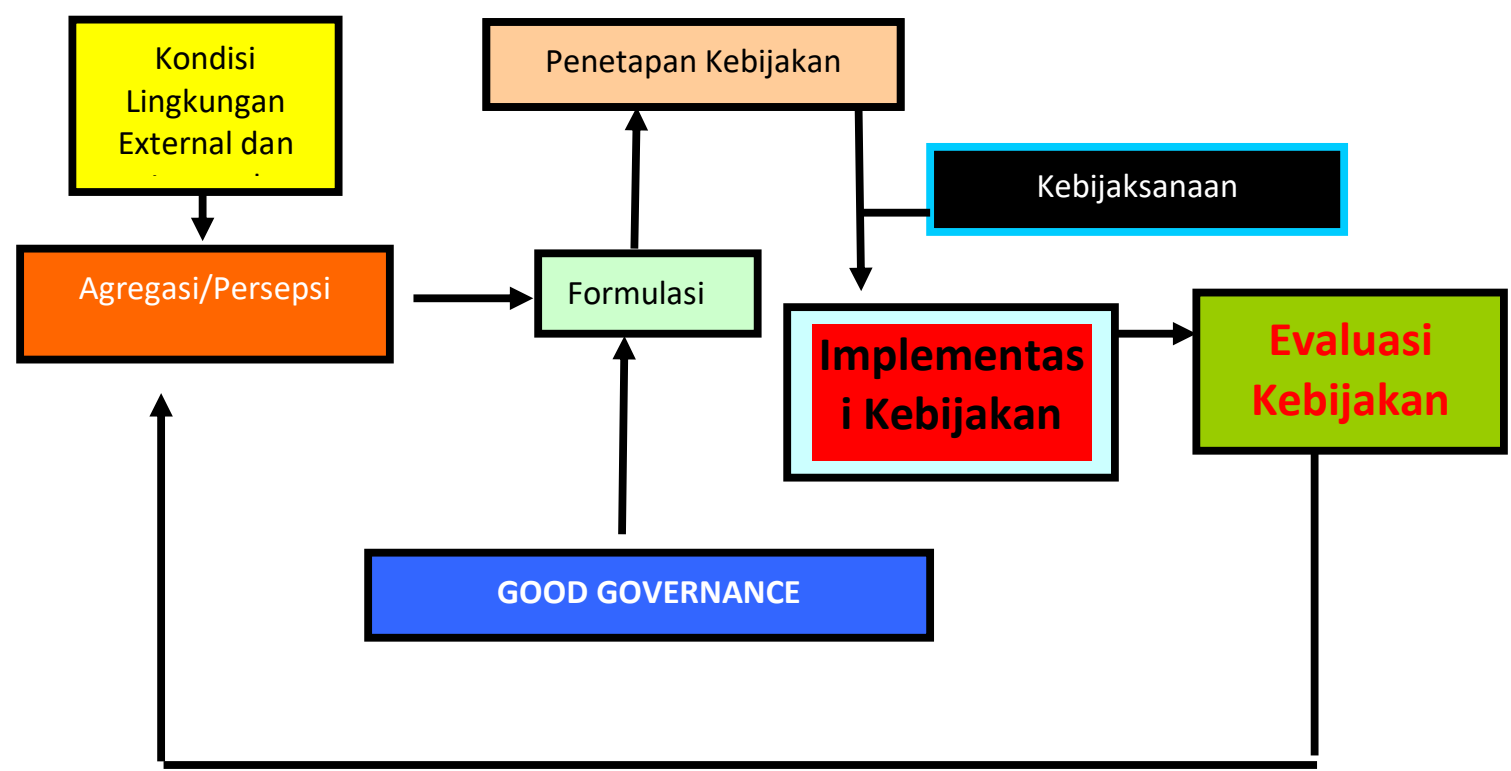

Makna dan hakekat kebijakan publik merupakan suatu keputusan yang dilaksanakan oleh Pejabat Pemerintah yang berwenang untuk kepentingan masyarakat (public interest). Kepentingan masyarakat ini merupakan keseluruhan yang utuh dari perpaduan dan kristalisasi pendapat-pendapat, keinginan-keinginan dan tuntutan-tuntutan (demands) dari rakyat. Edward dan Sharansky dalam Wahab (1997 : mengutarakan bahwa: "kebijakan public itu dapat ditetapkan secara jelas dalam peraturan-peraturan, perundang-undangan atau dalam bentuk pidato-pidato pejabat teras pemerintah ataupun berupa program-program dan tindakan-tindakan yang dilakukan pemerintah. Anderson memberikan pengertian kebijakan sebagai perilaku dari sejumlah aktor (pejabat, kelompok, instansi pemerintah) atau serangkaian aktor dalam suatu bidang kegiatan tertentu". 
Dalam proses kebijakan publik ini meliputi tahap-tahap :

(a) Perumusan kebijakan publik.

Tahap ini mulai dari perumusan masalah sampai dengan dipilihnya alternatif untuk direkomendasikan dan disahkan oleh pejabat yang berwenang.

(b) Implementasi kebijakan publik.

Setelah kebijakan publik disahkan oleh pejabat yangberwenang, maka kemudian kebijakan publik tersebut diimplementasikan (dilaksanakan). Mengenai implementasi kebijakan publik, Mustopadidjaja AR (Bintoro Tjokroamidjojo dan Mustopadidjaja AR. 1988)

(c) Monitoring kebijakan publik.

Monitoring kebijakan publik adalah proses kegiatan pengawasan terhadap implementasi kebijakan yaitu, untuk memperoleh informasi tentang seberapa jauh tujuan kebijakan itu tercapai. (Hogwood and Gunn, 1989).

(d) Evaluasi kebijakan publik.

Evaluasi kebijakan publik ini bertujuan untuk menilai apakah perbedaan sebelum dan setelah kebijakan itu diimplementasikan, yaitu perbandingan antara sebelum dan sesudah diberlakukannya suatu kebijakan.

Tahapan Kebijakan Publik dapat juga meliputi sebagai berikut : Identifikasi masalah kebijakan yaitu identifikasi masalah Kebijakan melalui tuntutan tindakan pemerintah. Agenda seting yaitu memfokuskan pada perhatian media massa atau pejabat publik (pemerintah) pada masalah masalah publik tertentu untuk memutuskan apa yang diputuskan. Efek media meliputu : identifikasi isu dan agenda setting untuk pengambil kebijakan, mempengaruhi sikap dan nilai ke arah isu kebijakan, mengubah perilaku voter dan pengambil keputusan.Formulasi Kebijakan yaitu merumuskan tujuan kebijakan untuk menyelesaikan masalah, melalui inisiasi dan perkembangannya dengan bagian perencanaan kebijakan, 
kepentingan kelompok, birkorasi pemerintah, Presiden dan Dewan. Rincian proposal kebijakan biasanya diformulasikan oleh staff yang dipandu oleh atasannya. Legitimasi Kebijakan yaitu menyeleksi proposal, membangun dukungan politik, mensahkannya menjadi UU. ( ada Tanda tangan pejabat yang mengesahkan dan stempel dari institusi yang berwenang. Melalui birokrasi yang teratur, pemberitaan publik dan kegiatan badan legislatif. Impementasi Kebijakan yaitu mengorganisir birokrasi, menyediakan belanja atau pelayanan publik, memungut pajak dan kegiatan - kegiatan lain dari badan legislative. Evaluasi Kebijakan, dalam evaluasi kebijakan program meliputi : mempelajari program, melaporkan output dari program pemerintah, evaluasi dampak kebijakan, mengusulkan perubahan kebijakan, dilakukan oleh pemerintah sendiri, konsultan luar, pers, dan publik

Dengan melihat teori atau konsep kebijakan publik yang telah diuraikan tersebut maka program KOTAKU tentang Kota Tanpa Kumuh merupakan out put kebijakan publik. Dan sekarang ini harus sudah dimulai tahapan selanjutnya yaitu evaluasi kebijakan pogram tersebut sdah tercapai. Sesuai dengan target RPJMN 2015-2020 untuk pencapaian target 0\% kawasan kumuh maka dilaksanakan Program KOTAKU dimana BKM (Badan Keswadayaan Masyarakat) menjadi mitra Pemerintah Desa/Kelurahan dalam penanganan Kawasan Permukiman dan Kawasan Kumuh.

Permukiman kumuh yaitu pemukiman yang tidak layak huni karena ketidakteraturan bangunan, tingkat kepadatan bangunan yang tinggi, dan kualitas bangunan serta sarana dan prasarana yang tidak memenuhi syarat, sedangkan Perumahan Kumuh adalah perumahan yang mengalami penurunan kualitas fungsi sebagai tempat hunian. Adapun indikator pemukiman kumuh yaitu :
(a) Kondisi Bangunan (Keteraturan Bangunan \& Kepadatan Bangunan)
(b) Jalan Lingkungan;
(c) Drainase Lingkungan;
(d) Penyediaan Air Bersih/Minum; 
(e) Pengelolaan Persampahan;

(f) Pengelolaan Limbah;

(g) Pengamanan Kebakaran; dan

(h) Ruang Terbuka Publik

Tujuan Program KOTAKU adalah meningkatkan akses terhadap infrastruktur dan pelayanan dasar di permukiman kumuh perkotaan untuk mendukung terwujudnya permukiman perkotaan yang layak huni, produktif dan berkelanjutan.

(1) Menurunnya luas permukiman kumuh;

(2) Terbentuknya Pokja PKP di tingkat Kab/Kota; dalam penanganan permukiman yang berfungsi dengan baik;

(3) Tersusunnya rencana penanganan permukiman kumuh tingkat kab/kota dan tingkat masyarakat yang terintegrasi dalam RPJMD;

(4) Meningkatkan penghasilan Masyarakat Berpenghasilan Rendah (MBR) melalui penyediaan infrastuktur dan kegiatan peningkatan penghidupan masyarakat untuk mendukung pencegahan dan peningkatan kualitas permukiman kumuh;

(5) Terlaksananya aturan bersama sebagai upaya perubahan perilaku hidup bersih dan sehat masyarakat dan pencegahan kumuh.

Prinsip dasar program KOTAKU :

(1) Pemda sebagai nahkoda;

(2) Perencanaan komprehensif dan berorientasi outcome (pencapaian tujuan program);

(3) Singkronisasi perencanaan dan penganggaran;

(4) Partisipatif;

(5) Kreatif dan Inovatif;

(6) Pengelolaan lingkungan dan sosial yang menjamin keberlanjutan program investasi KOTAKU harus memuat prinsip pembangunan berkelanjutan;

(7) Tata kelola pemerintahan yang baik (good governance); 
(8) Investasi penanganan permukiman kumuh disamping harus mendukung perkembangan kota juga harus mampu meningkatkan kapasitas dan daya dukung lingkungan;

(9) Revitalisasi peran BKM, penajaman peran BKM dari orientasi penanggulangan kemiskinan kepada orientasi pencegahan dan peningkatan permukiman kumuh.

Program KOTAKU terdiri dari komponen-komponen berikut dalam rangka pencapaian tujuan program :

(1) Pengembangan kelembagaan, strategy dan kebijakan;

(2) Pengembangan kapasitas untuk pemerintah daerah dan masyarakat termasuk dukungan untuk perencanaan penanganan permukiman kumuh yang terintegrasi;

(3) Pendanaan investasi untuk infrastruktur dan pelayanan perkotaan yang terdiri dari : a. Infrastruktur skala kawasan dan skala kab/kota terpilih; b. Pembangunan kawasan permukiman baru untuk MBR; c. Infrastruktur skala lingkungan, termasuk dukungan pengembangan penghidupan berkelanjutan.

(4) Dukungan pelaksanaan dan bantuan teknis;

(5) Dukungan program/kegiatan lainnya, termasuk dukungan untuk kondisi darurat bencana. 


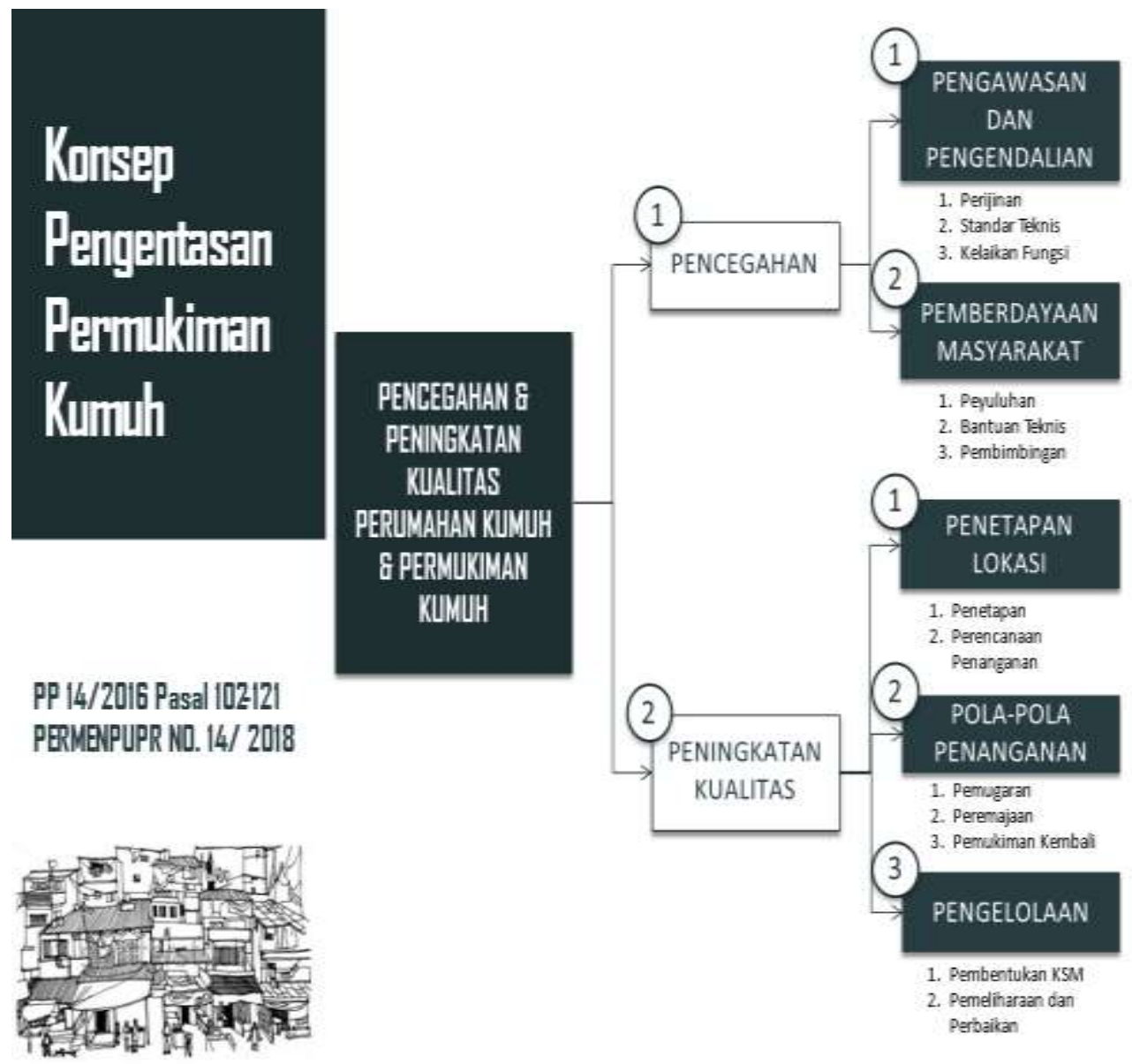

Bahwa persoalan kumuh, diyakini bukan hanya berbicara persoalan fisik semata- mata. Kekumuhan dalam paradigma pembangunan manusia, adalah akibat dari persoalan pembangunan itu sendiri. Dalam kehidupan berbangsa dan bernegara, Dari sisi negara, Kawasan kumuh bisa terjadi akibat dari kebijakan yang tidak berpihak pada kaum marjinal, tidak memberikan asas keadilan dalam menyediakan akses sarana, prasarana serta utilitas umum sebagai sandaran bagi permukiman masyarakat yang sehat dan layak huni. Dari sisi masyarakat, berbondong-bondongnya masyarakat ke kota misalnya, tanpa didukung dengan keahlian yang memadai, menyebabkan pilihan terhadap tempat tinggal menjadi sempit, belum lagi soal perilaku masyarakat yang kurang sehat, juga bisa mengakibatkan kawasan kumuh timbul. 


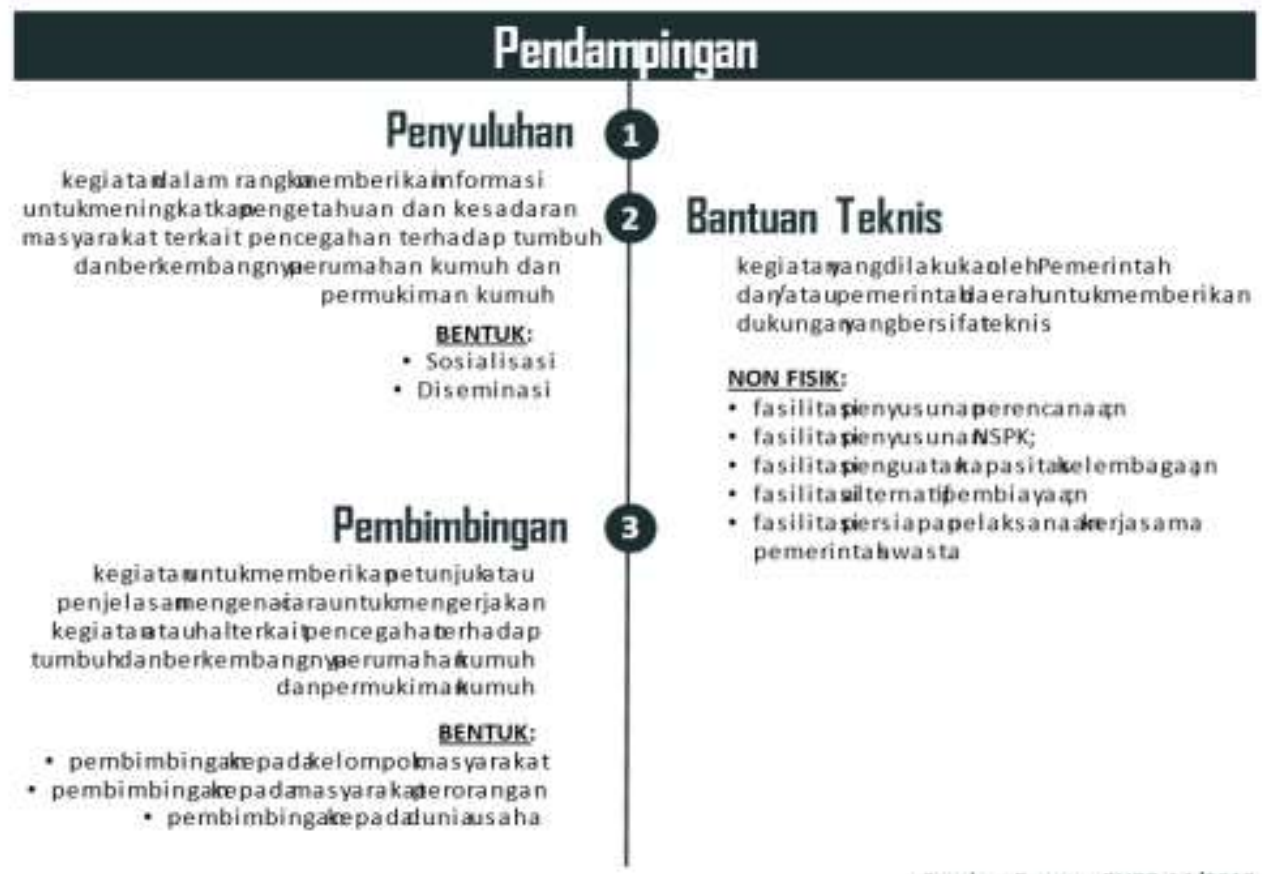

Program KOTAKU adalah program yang dilaksanakan secara nasional di $271 \mathrm{Kab} /$ Kota di 34 Provinsi yang menjadi "Platform kolaborasi" atau basis penanganan permukiman kumuh yang mengintegrasikan berbagai sumber daya dan sumber pendanaan, termasuk dari pemerintah pusat, provinsi, kabupaten/kota, donor, swasta, masyarakat dan pemangku kepentingan lainnya. Maka ada pertanyaan bagaimana Permasalahan Kumuh seluas 35.291 Ha seluruh Indonesia dapat diselesaikan pada Tahun 2019. Dengan pola pendampingan pemberdayaan masyarakat dengan penyuluhan, bantuan teknis dan pembimbingan yang intens kepada masyarakat maupun stakeholder yang terkait program KOTAKU yang mempunyai amanah menanggulangi kota tanpa kumuh bisa berhasil secara optimal.

\section{B. METODE PENELITIAN}

Metode yang digunakan dalam penelitian ini adalah metode penelitian deskriptif-kualitatif, yaitu berusaha menguraikan, menjelaskan penyebab suatu masalah berdasarkan data dan fakta yang ada. Pengambilan data 
Jurnal SOSIO DIALEKTIKA 6 (1) (2021)

P-ISSN: 2540.8941 e-ISSN: 2623.2944

sosiodialektika@unwahas.ac.id
Gambaran Program Kotaku

(Kota Tanpa Kumuh )

Kota Semarang Tahun 2019

(Studi Evaluasi Kebijakan)

dalam penelitian ini melalui studi pustaka (teknik library reseach), sehingga data yang diperoleh adalah data sekunder. Data sekunder adalah data yang diperoleh lewat pihak lain, tidak langsung diperoleh oleh peneliti dari subyek penelitiannya yaitu sumber-sumber tersebut didapatkan melalui studi literatur dan dokumen laporan termasuk akses data melalui website / internet. Dalam penelitian ini analisis datanya diperoleh melalui interpretasi dokumentasi yang terkumpul, kemudian dianalisis secara deskriptifkualitatif, yaitu mendeskripsikan suatu situasi atau area populasi tertentu bersifat faktual secara sistematis dan akurat

\section{HASIL DAN PEMBAHASAN}

\section{(1) Tinjauan Kota Semarang}

Lokasi sasaran program KOTAKU Kota semarang terdiri dari 177 Kelurahan tersebar di 16 Kecamatan. Program KOTAKU Kota Semarang mencakup 2 intervensi program kegiatan yaitu pencegahan dan peningkatan kualitas.

\section{Peta Kota Semarang}

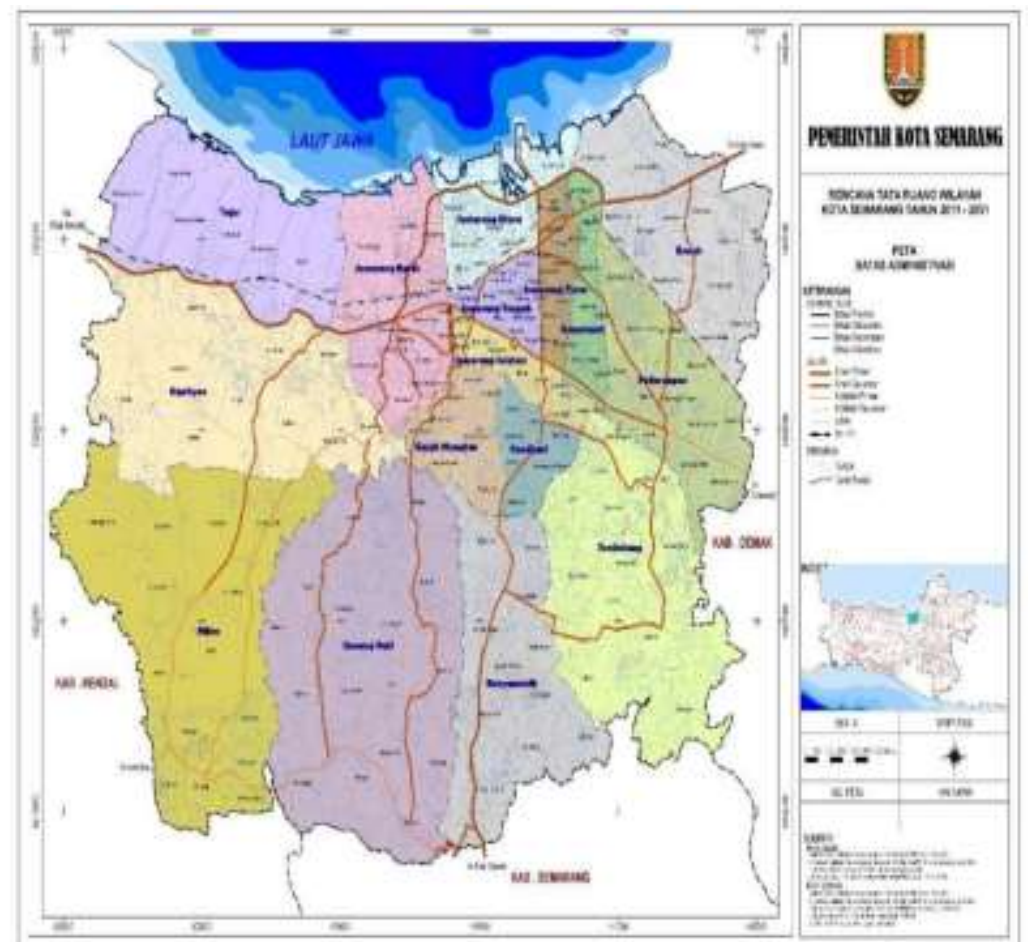

Sumber: BAPPEDA Kota Semarang, 2011 
Jurnal SOSIO DIALEKTIKA 6 (1) (2021)

P-ISSN: 2540.8941 e-ISSN: 2623.2944

sosiodialektika@unwahas.ac.id
Gambaran Program Kotaku

(Kota Tanpa Kumuh )

Kota Semarang Tahun 2019

(Studi Evaluasi Kebijakan)

Untuk lokasi peningkatan kualitas sebanyak 62 Kelurahan dan 115 untuk lokasi pencegahan. Kegiatan peningkatan kualitas lingkungan permukiman kumuh yang dilakukan oleh BAPPEDA Kota Semarang menghasilkan sebaran permukiman kumuh yang ada di Kota Semarang. Kegiatan Penanganan dilaksanakan mengacu pada Surat Keputusan (SK) Walikota Semarang No. 050/801/2014 tentang Penetapan Lokasi Lingkungan Perumahan dan Permukiman Kumuh di Kota Semarang.

Kota Semarang terletak antara garis $6^{\circ} 50^{\prime}-7^{\circ} 10^{\prime}$ LS dan garis $109^{\circ} 50^{\prime}-110^{\circ} 35^{\prime}$ BT, secara administratif Kota Semarang dibatasi oleh :

- Sebelah Utara

- Sebelah Selatan

- Sebelah Barat

- Sebelah Timur
: Laut Jawa

: Kota Semarang

: Kota Kendal

: Kota Demak

\begin{tabular}{|c|c|c|l|c|}
\hline No & Kecamatan & $\begin{array}{c}\text { Luas } \\
\text { Daerah } \\
\text { (Km2) }\end{array}$ & \multicolumn{1}{|c|}{ Kelurahan } & $\begin{array}{c}\text { Jumlah } \\
\text { Kelurahan }\end{array}$ \\
\hline 1 & Mijen & 55,75 & $\begin{array}{l}\text { Cangkiran, bubakan, Karang Malang, Polaman, Purwosari, Tambangan, } \\
\text { Jatisari, Mijen, Jati Barang, Kedung Pane, Pesantern, Ngadirgo, } \\
\text { Wonopolo, Wonoplumbon }\end{array}$ & 14 \\
\hline 2 & Gunung Pati & 54,11 & $\begin{array}{l}\text { GunungPati, Plalangan, Sumurrejo, Pakintelan, Mangunsari, Patemon, } \\
\text { Ngijo, Nongko Sawit, Cepoko, Jatirejo, Kandri, Pongangan, kali Segoro, } \\
\text { Sekaran, Sukorejo, Sadeng. }\end{array}$ & 16 \\
\hline 3 & Banyumanik & 25,69 & $\begin{array}{l}\text { Pundakpayung, Gedawang, Jabungan, Pandangsari, Banyumanik, } \\
\text { Srondol Wetan, Pedalangan, Sumur Boto, Srondol Kulon, Tinjomoyo, } \\
\text { Ngesrep }\end{array}$ & 11 \\
\hline 4 & Gajahmungkur & 9,07 & $\begin{array}{l}\text { Sampangan, Bendan Dhuwur, karangrejo, Gajah Mungkur, Bendan } \\
\text { Ngisor, Petompon, Bendungan, Lempongsari }\end{array}$ & 08 \\
\hline 5 & $\begin{array}{c}\text { Semarang } \\
\text { Selatan }\end{array}$ & 5,93 & $\begin{array}{l}\text { Bulustalan, Barusari, Randusari, mugasari, pleburan, Wonodri, } \\
\text { Peterongan, Lamper Kidul, Lamper Lor, Lamper Tengah }\end{array}$ & 10 \\
\hline 7 & Candisari & 6,54 & $\begin{array}{l}\text { Jatingaleh, Karanganyar gunung, Jomblang, candi, kaliwiru, Wonotingal, } \\
\text { Tegalsari }\end{array}$ & 07 \\
\hline
\end{tabular}


Jurnal SOSIO DIALEKTIKA 6 (1) (2021)

P-ISSN: 2540.8941 e-ISSN: 2623.2944

sosiodialektika@unwahas.ac.id
Gambaran Program Kotaku

(Kota Tanpa Kumuh )

Kota Semarang Tahun 2019

(Studi Evaluasi Kebijakan)

\begin{tabular}{|c|c|c|l|c|}
\hline 8 & Pedurungan & 20,72 & $\begin{array}{l}\text { Jgemah, Pedrungan Kidul, Pedurungan Lor, Tlogomulyo, Pedurungan } \\
\text { Tengah, Palebon, Kalicari, Tlogosari Kulon, Tlogosari Wetan, } \\
\text { Muktiharjo Kidul }\end{array}$ & 12 \\
\hline 9 & Genuk & 27,39 & $\begin{array}{l}\text { Muktiharjo Lor, Gebangsari, Genuksari, Bangetayu Kulon, Bangetayu } \\
\text { wetan, Sembungharjo, Penggaron Lor, Kudu, Karangroto, Banjardowo, } \\
\text { Trimulyo, Terboyo wetan, Terboyo Kulon }\end{array}$ & 13 \\
\hline 10 & Gayamsari & 6,18 & $\begin{array}{l}\text { Pandean lamper, Gayamsari, Siwalan, Sambirejo, Sawah Besar, Kaligawe, } \\
\text { Tambakrejo }\end{array}$ & 07 \\
\hline 11 & $\begin{array}{c}\text { Semarang } \\
\text { Timur }\end{array}$ & 7,70 & $\begin{array}{l}\text { Karang Turi, Karangtempel, Rejosari, sarirejo, Kebon Agung, Bugangan, } \\
\text { Mlatiharjo, Mlatibaru, Rejomulyo, Kemijen }\end{array}$ & 10 \\
\hline 12 & $\begin{array}{c}\text { Semarang } \\
\text { Utara }\end{array}$ & 10,97 & $\begin{array}{l}\text { Bulu Lor, Plombokan, } \\
\text { Panggung Kidul, Panggung Lor, Kuningan, Purwosari, Dadapsari, } \\
\text { Bandarharjo, Tanjung Emas }\end{array}$ & 09 \\
\hline 14 & $\begin{array}{c}\text { Semarang } \\
\text { Tengah }\end{array}$ & 6,14 & $\begin{array}{l}\text { Pekunden,Karang Kidul,Jagalan, Brumbungan, Miroto, Gabahan, } \\
\text { Kranggan, Purwodinatan, Kauman, Bangunharjo, Kembang Sari, Pandan } \\
\text { sari, Sekayu, Pindrikan Kidul, Pindrikan Lor Kembang Arum, Manyaran, } \\
\text { Ngemplak simongan, Bongasari, Bojong }\end{array}$ & 15 \\
\hline 15 & Semarang & 21,74 & $\begin{array}{l}\text { Salaman, Cabean, Salaman Mloyo, Gisikdrono, Kalibanteng Kidul, } \\
\text { Kalibanteng Kulon, Krapyak, Tambakharjo, Tawangsari, Karang ayu, } \\
\text { Krobokan, Tawangmas }\end{array}$ & 16 \\
\hline 16 & Tugu & 31,78 & $\begin{array}{l}\text { Jrakah, Tugurejo, Karang Anyar, Randugarut, Mangkang Wetan, } \\
\text { Mangunharjo, Mangkang Kulon }\end{array}$ & 22 \\
\hline
\end{tabular}

Sumber : Kota Semarang Dalam Angka, 2015

Melihat luas wilayah Kota Semarang yang memiliki 16 kecamatan dan 177 kelurahan merupakan suatu kota yang tergolong luas luas wilayahnya. Apalagi belum teridentifikasi jumlah penduduk dan persebarannya. Dengan persebaran Kelurahan per Kecamatan sudah bisa dibayangkan Kota Semarang merupakan Ibukota Provinsi Jawa Tengah pasti cenderung memiliki Kawasan kumuh atau kantongkantong kemiskinan yang tersebar maupun terpusat pada pemukiman kumuh maupun area atau daerah yang memiliki potensi ekonomi sebagai lahan mata pencaharian masyarakat kota

\section{(2) Persebaran Program KOTAKU Kota Semarang}

Persebaran Kelurahan per Kecamatan sangat menarik kita kaji khususnya terkait wilayah kumuh, karena bisa kita kategorikan menjadi 3 daerah, yaitu ada kelurahan di daerah kecamatan perkotaan dekat dengan ibukota Provinsi, ada juga yang berdekatan dengan daerah pesisir dan ada juga daerah pegunungan (daerah atas). Maka 
Jurnal SOSIO DIALEKTIKA 6 (1) (2021)

P-ISSN: 2540.8941 e-ISSN: 2623.2944

sosiodialektika@unwahas.ac.id
Gambaran Program Kotaku

(Kota Tanpa Kumuh )

Kota Semarang Tahun 2019

(Studi Evaluasi Kebijakan)

tingkat kemiskinan dan karakteristik kemiskinannya juga berbeda bahkan tingkat kekumuhannya juga berbeda. Tabel Sebaran lokasi kawasan kumuh beserta luas kawasan kumuh di Kota Semarang.Surat

Keputusan Walikota Semarang Nomer : 050/801/2014 Penetapan

Kawasan Permukiman Kumuh Kota Semarang.

Tabel Sebaran Lokasi Kawasan Kumuh Kota Semarang 2014

\begin{tabular}{|c|c|c|c|c|c|c|c|}
\hline \multirow{2}{*}{ No. } & \multicolumn{2}{|c|}{ Lokasi } & \multirow{2}{*}{$\begin{array}{l}\text { LUAS } \\
\text { (Ha) }\end{array}$} & \multirow{2}{*}{ No. } & \multicolumn{2}{|c|}{ Lokasi } & \multirow{2}{*}{$\begin{array}{l}\text { LUAS } \\
\text { (Ha) }\end{array}$} \\
\hline & Kecamatan & Kelurahan & & & Kecamaton & Kelurahan & \\
\hline \multirow[t]{3}{*}{1} & Tugu & Mangunharjo & 1.56 & 8 & Pedurungan & Gemah & 5.50 \\
\hline & & Mangkangwetan & 3.79 & & & Muktiharjo Kidul & 13.76 \\
\hline & & Mangkang Kulon & 13.59 & & & Penggaron Kidul & 2.19 \\
\hline \multirow[t]{4}{*}{2} & Genuk & Genuksari & 6.19 & 9 & Semarang Selatan & Lamper Lor & 4.71 \\
\hline & & Banjardowo & 3.38 & & & Lamper Kidul & 1.53 \\
\hline & & Terboyo Kulon & 0.62 & & & Peterongan & 1.33 \\
\hline & & Trimulyo & 6.00 & & & Lamper Tengah & 7.39 \\
\hline \multirow[t]{3}{*}{3} & Semarang Barat & Tambakharjo & 2.67 & 10 & Tembalang & Tandang & 3.12 \\
\hline & & Ngemplaksimongan & 1.32 & & & Sendangguwo & 4.36 \\
\hline & & Krobokan & 16.16 & & & Rowosari & 7.07 \\
\hline \multirow[t]{8}{*}{4} & Semarang Tengah & Brumbungan & 2.68 & & & Meteseh & 10.42 \\
\hline & & Bangunharjo & 4.00 & 11 & Gayamsari & Sawahbesar & 6.14 \\
\hline & & Kembangsari & 5.00 & & & Kaligawe & 7.35 \\
\hline & & Jagalan & 1.36 & & & Tambakrejo & 5.23 \\
\hline & & Miroto & 7.00 & & & Gayamsan & 1.57 \\
\hline & & Kauman & 2.00 & 12 & Mijen & Purwosari & 3.45 \\
\hline & & Pekunden & 5.00 & & & Jatibarang & 0.86 \\
\hline & & Sekayu & 2.32 & 13 & Banyumanik & Ngesrep & 0.59 \\
\hline \multirow[t]{6}{*}{5} & Semarang Timur & Bugangan & 8.34 & & & Padangsari & 0.49 \\
\hline & & Rejosari & 1.30 & & & Jabungan & 11.68 \\
\hline & & Mlatiharjo & 11.52 & & & Tinjomoyo & 5.53 \\
\hline & & Mlatibaru & 3.93 & & & Srondol Kulon & 3.67 \\
\hline & & Rejomulyo & 8.43 & & & Gedawang & 5.54 \\
\hline & & Kemijen & 15.86 & 14 & Gunungpati & Patemon & 0.14 \\
\hline \multirow[t]{5}{*}{6} & Semarang Utara & Tanjungmas & 37.63 & & & Sekaran & 3.19 \\
\hline & & Bandarhario & 33.44 & & & Sadeng & 2.47 \\
\hline & & Panggungkidul & 26 & & & Sukorejo & 2.6 \\
\hline & & Kuningan & 23.09 & & & Nongkosawit & 3.77 \\
\hline & & Dadapsari & 27.24 & 15 & Ngaliyan & Wonosan & 3.12 \\
\hline \multirow[t]{3}{*}{7} & Candisari & Jomblang & 1.1 & & & Kalipancur & 1.32 \\
\hline & & Karanganyargunung & 1.67 & & & Purwoyoso & 1.65 \\
\hline & & & & \multicolumn{3}{|c|}{ Total } & 415.83 \\
\hline
\end{tabular}


Jurnal SOSIO DIALEKTIKA 6 (1) (2021)

P-ISSN: 2540.8941 e-ISSN: 2623.2944

sosiodialektika@unwahas.ac.id
Gambaran Program Kotaku

(Kota Tanpa Kumuh )

Kota Semarang Tahun 2019

(Studi Evaluasi Kebijakan)

\section{Gambaran Program KOTAKU (Evaluasi Program KOTAKU Kota}

Semarang Tahun 2019)

Evaluasi Program KOTAKU yaitu Kegiatan Pengurangan Kumuh Kota Semarang Tahun 2017 sebagai berikut terlihat dalam table :

Tabel Pengurangan Kumuh Kota Semarang Tahun 2017

\begin{tabular}{|c|c|c|c|c|c|c|}
\hline No & Kelurahan & Kecamatan & $\begin{array}{c}\text { Luas Kumuh } \\
\text { Awal (Ha) }\end{array}$ & $\begin{array}{l}\text { Luas Kumuh } \\
\text { Akhir (Ha) }\end{array}$ & $\begin{array}{l}\text { Pengurangan } \\
\text { Kumuh (Ha) }\end{array}$ & $\begin{array}{l}\text { Penguranean } \\
\text { Kumuh ( } \mathbf{6} \text { ) }\end{array}$ \\
\hline 1 & Gemah & Pedurungan & 5.50 & 0.00 & 5.50 & 109005 \\
\hline 2 & Pekunden & Semarang Tengah & 5.00 & 0.00 & 5,00 & 100005 \\
\hline 3 & Tambakharjo & Semarane Barat & 2.67 & 0.00 & 267 & $100.00 \mathrm{~s}$ \\
\hline 4 & Sukorejo & Gunungpati & 2.60 & 0.00 & 260 & 100008 \\
\hline 5 & Sekryu & Semarang Tengah & 2.32 & 0.00 & 2.32 & tooroos \\
\hline 6 & Gayamsari & Gayamsari & 157 & 0.00 & 157 & $10000 \%$ \\
\hline 7 & Kalipancur & Nealiyan & 132 & 0.00 & 132 & 100905 \\
\hline 8 & Ngemplak Simongan & Semaran\& Batat & 1.32 & 0.00 & 2.32 & 100.005 \\
\hline 9 & Rejosari & Semarang Timur & 130 & 0.00 & 139 & $10000 \mathrm{~s}$ \\
\hline 10 & Nglestep & Banyumanik & 0.59 & 0.00 & 059 & $10000 \mathrm{~s}$ \\
\hline 11. & Patemon & Gunungpeti & 0.14 & 0.00 & 0.14 & 100005 \\
\hline 12 & Rejomulyo & Semarand Timur & 8.43 & 0.13 & 830 & $9=468$ \\
\hline 13 & Panggund Kidul & Semarang Utara & 26.00 & 269 & 2331 & 89685 \\
\hline 14 & Bugandan & Semarang Timur & 8.34 & 165 & 6.69 & $8022 \pi$ \\
\hline 15 & Krobokan & Semarang Barat & 16.16 & 3.70 & $12.4 \mathrm{G}$ & $7710 \mathrm{~s}$ \\
\hline 16 & Tandang & Tembalang & 3.12 & 0.88 & 224 & 71.795 \\
\hline 17 & Tiniomoyo & Banyumanik & 5.53 & 158 & 3.95 & $7143 \%$ \\
\hline 18 & Gedawang & Banyumanik & 5.54 & 167 & 3.87 & $69.86 \%$ \\
\hline 19 & Purwoyoso & Ngaliyan & 165 & 0.55 & 110 & $66.67 \%$ \\
\hline 20 & Peterongan & Semarane Selatan & 133 & 0.54 & 0.79 & 59.4036 \\
\hline 21 & Kembangsari & Semarang Tengah & 5.00 & 2.30 & $2.7 a^{\prime}$ & $54.00 \%$ \\
\hline 22 & Jombiane & Candisari & 1.10 & 0.52 & 0.58 & 52.7326 \\
\hline 23 & Terboyo Kulon & Genuk & 0.62 & 0.30 & 0.32 & $51.61 \%$ \\
\hline 24 & Karanganyar Gunung & Candisan & 167 & 0.82 & 0.85 & 509014 \\
\hline 25 & Wonosari & Nidaliyan & 3.12 & 155 & 1.57 & $5032 \%$ \\
\hline 26 & Miroto & Semarand Tengah & 7.00 & 3.58 & 3.42 & $48.86 \%$ \\
\hline 27 & Rowosari & Tembalang & 707 & 3.82 & 3.25 & 43978 \\
\hline 28 & Semah Besar & Gayamsari & 6.14 & 3.69 & 2.45 & $39.90 \mathrm{~K}$ \\
\hline 29 & Lamper Tengah. & Semarank Selatan & 739 & 4.60 & 2.79 & 37.754 \\
\hline 30 & Sedeng & Ounungeat & 247 & 254 & 0.93 & 37.654 \\
\hline 31 & Kaligawe & Gayamsari & 7.35 & 4.86 & 249 & $33.88 \mathrm{~K}$ \\
\hline 32 & Trimulye & Genuk & 600 & 4.69 & 132 & 21834 \\
\hline 34 & Lampor Lor & Semaranc Selotan & 4.71 & 3.75 & 0.96 & 20.396 \\
\hline 35 & Miatibaru & Semarang Timur & 3.93 & 3.28 & 0.65 & 16.545 \\
\hline 36 & Brumbungan & Semarang Tercan & $2 \mathrm{es}$ & 224 & 0.44 & $16.42 \%$ \\
\hline 37 & Bangunharjo & Somarang Tentah & 400 & 347 & 0.53 & $1335 \mathrm{~s}$ \\
\hline 38 & Genuiksari & Oenuk & 6.19 & 5.59 & $0, d$ & $969 \%$ \\
\hline 39 & Miatinario & Semarane Timur & 1152 & 1095 & 0.57 & $4.95 \pi$ \\
\hline 40 & Lamper Kidue & Semarane Selatan & 153 & 153 & 0.09 & 0008 \\
\hline 41 & Jacolan & Somarang Tengah & 136 & 136 & 000 & $000 x$ \\
\hline 42 & Kauman & Semarane Tengah & 200 & 200 & 0,00 & $0.00 \%$ \\
\hline 43 & Mangunharje & Tugu & 156 & 156 & 0.09 & $0.00 \mathrm{k}$ \\
\hline 44 & Mangians Kulon & Tugu & 3.78 & 3.79 & 0.00 & $0,00 \mathrm{x}$ \\
\hline 45 & Sekaran & Gununesat & 3.19 & 3.19 & 0.00 & 0.008 \\
\hline 46 & Nongkosawit & Oununepat: & 3.77 & 377 & 0,00 & 0,008 \\
\hline 47 & Purwosari & Mien & 3.45 & 3.45 & 0.00 & 0008 \\
\hline 48 & Jatibarang & Mijen & 086 & 0.86 & 000 & 0.006 \\
\hline 49 & Srondol Kulon & Banyumanik & 3.67 & 3.67 & 0,09 & 0008 \\
\hline so & Peclancion & Bamyumanik & 049 & 0.49 & 0.00 & 0.001 \\
\hline 51 & Pancsaron Kidul & Peduruncen & 2.19 & 2.19 & 0.09 & 0.005 \\
\hline 52 & Banjardowe & Genuk & 3.35 & 3.38 & 000 & 0.008 \\
\hline 53 & Tambakrejo & Ooyameari & 5.23 & 5.23 & 0.00 & 0.005 \\
\hline 54 & Muktithario Kidul & Pedurungan & 13.78 & 13.76 & 000 & 0,008 \\
\hline 55 & Manchang wetan & Tugu & 1359 & 1359 & 0.09 & $0.00 \%$ \\
\hline 56 & Kemien & Semarane Timur & 15.86 & 15.86 & 0.09 & 0008 \\
\hline 57 & Toniunemas. & Semarane Utara & 37.69 & 37.63 & 0,00 & 0.004 \\
\hline 58 & Bandartiarjo & Semarang Utara & 3344 & 33.44 & $\infty \propto 0$ & $0,00 \%$ \\
\hline 59 & Kuningen & Semarang Utare & 23.09 & 23.09 & 0.00 & 0,008 \\
\hline 60 & Dadapeari & Semarangutars & 27.24 & 2724 & 0,09 & 0.005 \\
\hline 61 & Jabunsan & Bonyumanik & 1168 & 1168 & 0.00 & $0.00 \mathrm{~s}$ \\
\hline \multirow[t]{2}{*}{62} & Meteseh & Tembalang & 10.42 & 10.42 & 0.00 & $0.00 \mathrm{~N}$ \\
\hline & Sumlah & & 415.93 & 30158 & 114.36 & 27.496 \\
\hline
\end{tabular}

Sumber : Kota Semarang Dalam Angka, 2015 
Jurnal SOSIO DIALEKTIKA 6 (1) (2021)

P-ISSN: 2540.8941 e-ISSN: 2623.2944

sosiodialektika@unwahas.ac.id
Gambaran Program Kotaku

(Kota Tanpa Kumuh )

Kota Semarang Tahun 2019

(Studi Evaluasi Kebijakan)

Pada tahun 2017 telah mencapai pengurangan kumuh yang menggembirakan dari sebagian yang termasuk Kelurahan kumuh dan sebagian juga sudah ada pergerakan menuju penggurangan daerah kumuh. Dari berbagai kegiatan program KOTAKU menjadikan daerah-daerah kumuh berubah menjadi pemandangan yang menyenangkan pada semua yang fihak yang dulu terlihat daerah tidak teratur dan tidak sedap dipandang mata, menjadikan daerah yang terkesan indah dan tertata rapi asri.

Gambaran capaian penanganan kumuh Kota Semarang pada tahun 2019 sebagian besar berjalan dengan baik dan sesuai proses yang ada. Sebelumnya dapat digambarkan proses dari awalnya penangganan kumuh Kota Semarang sebagai berikut.

\section{Aspek Normatif}

\section{IMPLEMENTASI PENANGANAN KUMUH SESUAI PERATURAN PERUNDANDANGAN}

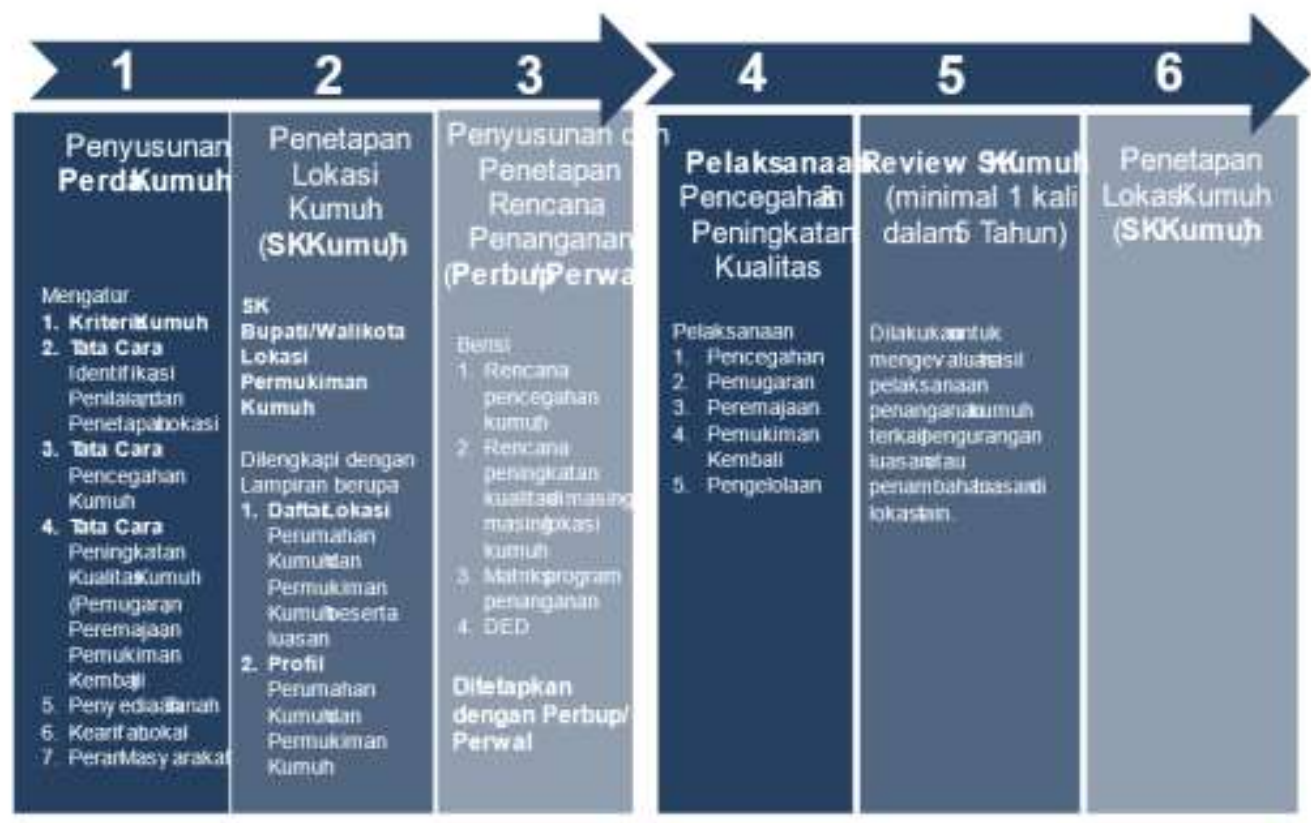

Dengan implementasi kebijakan KOTAKU sesuai peraturan perundangan yang berlaku, kota Semarang dalam pelaksanaan KOTAKU (Kota Tanpa Kumuh) cukup berhasil dapat mengurangi daerah kumuh atau pemukiman yang kumuh seperti tahun yang lalu. Dari tahun 2017 sebesar 142,14 ha, pada tahun 2018 menjasdi sebesar 121,45 ha dan pada tahun 
Jurnal SOSIO DIALEKTIKA 6 (1) (2021)

P-ISSN: 2540.8941 e-ISSN: 2623.2944

sosiodialektika@unwahas.ac.id
Gambaran Program Kotaku

(Kota Tanpa Kumuh )

Kota Semarang Tahun 2019

(Studi Evaluasi Kebijakan)

2019 luas kawasan kumuh menjadi 34,63 ha yang sangat signifikan penurunannya. Gambaran capaian pengurangan daerah wilayah kumuh dapat dilihat dalam tabel beriku ini.

\begin{tabular}{|c|c|c|c|c|c|c|c|c|c|c|}
\hline No & \multicolumn{3}{|c|}{ KECAMATAN } & \multicolumn{3}{|c|}{ KELURAHAN } & $\begin{array}{c}\text { LUAS } \\
\text { KUMUH } \\
\text { AWAL } 2019\end{array}$ & $\begin{array}{c}\text { LUAS } \\
\text { KUMUH } \\
\text { AKHIR } 2019\end{array}$ & \multicolumn{2}{|c|}{$\begin{array}{c}\text { HASIL } \\
\text { PENGURANGAN }\end{array}$} \\
\hline 1 & \multicolumn{3}{|c|}{ GENUK } & \multicolumn{3}{|c|}{ TRIMULYO } & 1,66 & - & \multicolumn{2}{|r|}{1,66} \\
\hline 2 & \multicolumn{3}{|c|}{ TUGU } & \multicolumn{3}{|c|}{ MANGKANG WETAN } & 7,36 & 7,10 & & 0,27 \\
\hline 3 & \multicolumn{3}{|c|}{ SEMARANGUTARA } & \multicolumn{3}{|c|}{ DADAPSARI } & 23,08 & 22,72 & & 0,36 \\
\hline 4 & \multicolumn{3}{|c|}{ CANDISARI } & \multicolumn{3}{|c|}{ JOMBLANG } & 0,52 & - & & 0,52 \\
\hline 5 & \multicolumn{3}{|c|}{ SEMARANGTENGAH } & \multicolumn{3}{|c|}{ KEMBANGSARI } & 0,30 & - & & 0,30 \\
\hline 6 & \multicolumn{3}{|c|}{ GENUK } & \multicolumn{3}{|c|}{ TERBOYO KULON } & 0,30 & - & & 0,30 \\
\hline 7 & \multicolumn{3}{|c|}{ BANYUMANIK } & \multicolumn{3}{|c|}{ PADANGSARI } & 0,49 & 0,12 & & 0,37 \\
\hline 8 & \multicolumn{3}{|c|}{ SEMARANGUTARA } & \multicolumn{3}{|c|}{ KUNINGAN } & 15,76 & 15,30 & & 0,46 \\
\hline 9 & \multicolumn{3}{|c|}{ SEMARANGTIMUR } & \multicolumn{3}{|c|}{ KEMIJEN } & 3,63 & 3,11 & & 0,52 \\
\hline 10 & \multicolumn{3}{|c|}{ SEMARANG SELATAN } & \multicolumn{3}{|c|}{ PETERONGAN } & 0,54 & - & & 0,54 \\
\hline 11 & \multicolumn{3}{|c|}{ NGALIYAN } & \multicolumn{3}{|c|}{ PURWOYOSO } & 0,55 & - & & 0,55 \\
\hline 12 & \multicolumn{3}{|c|}{ SEMARANGUTARA } & \multicolumn{3}{|c|}{ BANDARHARJO } & 26,00 & 25,22 & & 0,78 \\
\hline 13 & \multicolumn{3}{|c|}{ CANDISARI } & KAR & IGANYAR G & UNUNG & 0,82 & - & & 0,82 \\
\hline 14 & & NUNGPATI & & SAD & & & 1,54 & - & & 1,54 \\
\hline 15 & & DURUNGAN & & $\mathrm{MU}$ & HARJO KID & & 9,51 & 8,00 & & 1,51 \\
\hline 16 & SEN & AARANGSEL & TAN & LAN & R KIDUL & & 1,53 & - & & 1,53 \\
\hline 17 & & ALIYAN & & Wo & SARI & & 1,55 & - & & 1,55 \\
\hline 18 & TU & GU & & MAI & UNHARJO & & 1,56 & - & & 1,56 \\
\hline 19 & & MARANGUT & & TAN & NGMAS & & 29,89 & 28,12 & & 1,77 \\
\hline 20 & & DURUNGAN & & PEN & ARON KID & & 2,19 & - & & 2,19 \\
\hline 21 & SEN & AARANGSEL & TAN & LAN & R LOR & & 3,23 & 0,77 & & 2,46 \\
\hline 22 & SEN & IARANGSEL & TAN & LAN & R TENGAH & & 4,60 & - & & 4,60 \\
\hline 23 & & NYUMANIK & & $\mathrm{JAB}$ & GAN & & 11,68 & 3,21 & & 8,47 \\
\hline & & & & & & & 148,29 & 113,66 & & 34,63 \\
\hline & & Tahun 2 & & & & hun 201 & & & ahun 20 & \\
\hline $\begin{array}{l}\text { Aw } \\
(H C\end{array}$ & & $\begin{array}{l}\text { Akhir } \\
(\mathrm{Ha})\end{array}$ & Pen & $\operatorname{san}$ & $\begin{array}{l}\text { Awal } \\
(\mathrm{Ha})\end{array}$ & $\begin{array}{l}\text { Akhir } \\
(\mathrm{Ha})\end{array}$ & $\begin{array}{c}\text { Pengurangan } \\
(\mathrm{Ha})\end{array}$ & $\begin{array}{l}\text { Awal } \\
(\mathrm{Ha})\end{array}$ & $\begin{array}{l}\text { Akhir } \\
(\mathrm{Ha})\end{array}$ & $\begin{array}{c}\text { Pengur } \\
\text { angan } \\
\text { (Ha) }\end{array}$ \\
\hline 411 & & 269,74 & & & 269,74 & 148,29 & 121,45 & 148,29 & 113,66 & 34,63 \\
\hline
\end{tabular}

Sumber : Laporan Korkot KOTAKU Seamarang \& Kota Semarang Dalam Angka, 
Jurnal SOSIO DIALEKTIKA 6 (1) (2021)

P-ISSN: 2540.8941 e-ISSN: 2623.2944

sosiodialektika@unwahas.ac.id
Gambaran Program Kotaku

(Kota Tanpa Kumuh )

Kota Semarang Tahun 2019

(Studi Evaluasi Kebijakan)

Adapun Kecamatan atau Kelurahan yang mendapatkan BPM pada tahun 2019 di kota Semarang ada 5 kematan dan di 5 Kelurahan. Yaitu sbb :

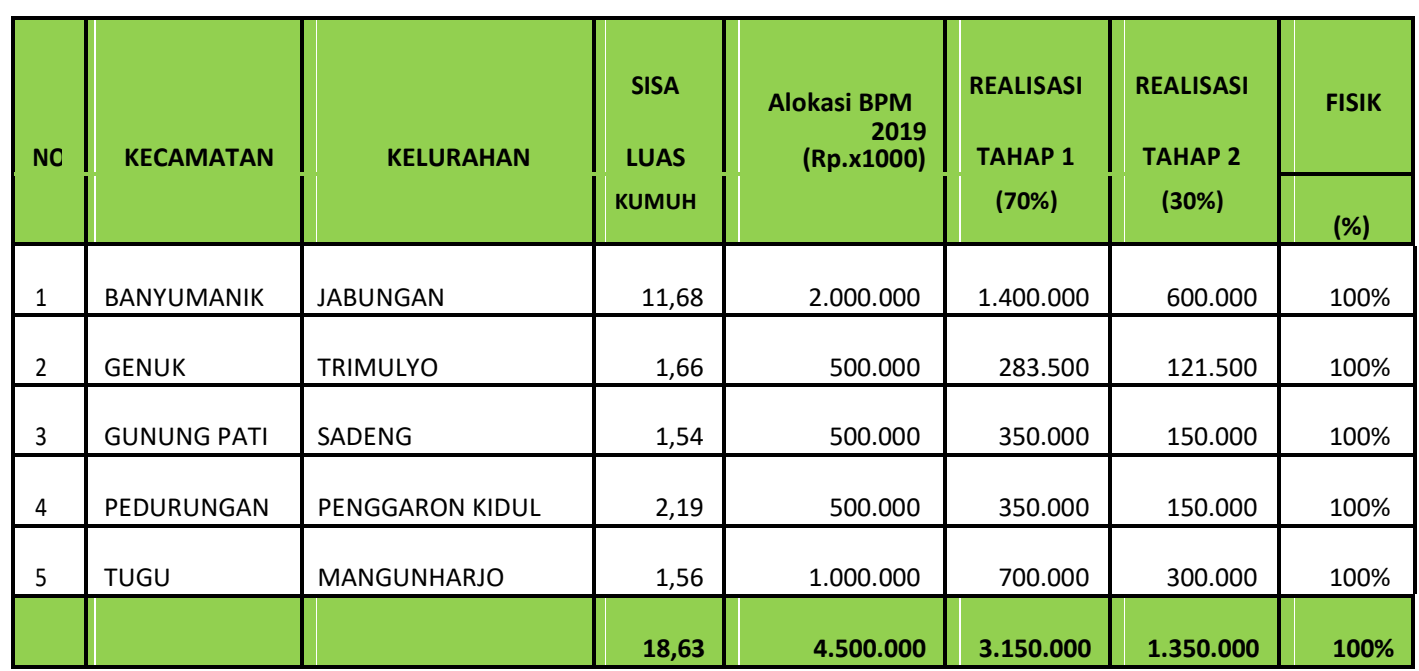

Sumber : Laporan Korkot KOTAKU Seamarang \& Kota Semarang Dalam Angka, 2019

Dengan melihat capaian lokasi yang terdanai BPM mencapai progress yang maksimal, maka kegiatan yang dilakukan pada tahapan berikutnya yaitu melakukan identifikasi kegiatan yang masih tersisa dalam rangka percepatan pengurangan kumuh dan melakukan persiapan status kumuh belum selesai. Adapun kegiatan Peningkatan Kapasitas Masyarakat secara umum di Kota Semarang sudah berjalan sesuai target dan terlaksana $100 \%$. Adapun untuk realisasi anggaran bersumber dari APBN untuk wilayah yang mendapatkan BPM

Kegiatan pemanfaatan BPM tahun 2019 selalu didampingi / fasilitasi percepatan pemanfaatan Bantuan Pemerintah Untuk Masyarakat (BPM) tahun 2019 dan juga fasilitasi Penyusunan Laporan Pertanggungjawaban pelaksanaan pemanfaatan BPM TA 2019. Adapun kegiatan yang dilakukan tahun 2019 di Tingkat Masyarakat : Fasilitasi Penyempurnaan Penyusunan dokumen Review RPLP, Fasilitasi Sinergi RPLP dlm Forum MusrenbangKel, , Fasilitasi sosialisasi dan pelaksanaan audit independen bagi BKM, Fasilitasi Pelaksanaan PKM, Fasilitasi pelaksanaan Kolaborasi. 
Jurnal SOSIO DIALEKTIKA 6 (1) (2021)

P-ISSN: 2540.8941 e-ISSN: 2623.2944

sosiodialektika@unwahas.ac.id
Gambaran Program Kotaku

(Kota Tanpa Kumuh )

Kota Semarang Tahun 2019

(Studi Evaluasi Kebijakan)

Sedangkan Kegitan di Tingkat Kota, Fasilitasi Penyempurnaan Penyusunan dan Pengesahan dokumen RP2KPKP, Fasilitasi siklus Kota, Fasilitasi FKA BKM, Sosialisasi dan Rakor tk Kota, Fasilitasi penyiapan kegiatan skala kawasan Kaligawe Sawah Besar, Fasilitasi pelaksanaan Kolaboras (Laporan Korkot Seamarang, 2019)

\section{E. SIMPULAN}

Secara umum pelaksanaan kegiatan KOTAKU kota Seamarang dapat terlaksana cukup baik. Adapun untuk pelaksanaan kegiatan di lapangan pemantauan dan evaluasi di tingkat Kelurahan berjalan cukup baik. Kegiatan-kegiatan yang sudah direncanakan terlaksana dengan baik akan tetapi waktu pelaksanaannya mengalami keterlambatan dari master schedule yang telah ditentukan dengan kendala dan permasalahan sesuai dengan kondisi masing-masing wilayah.

Dokumen Profil Kawasan Permukiman, Data 100-0-100 dan Indikasi kegiatan Percepatan Penanganan Kumuh tingkat Kota perlu ditindaklanjuti dan dijadikan dasar penyusunan program. Dokumen RPLP dan RP2KPKP ditindaklanjuti dan dijadikan dasar realisasi penanganan Kumuh dan Pencegahannya. Sisa kumuh di 10 Kelurahan perlu segera mendapatkan prioritas penanganan agar bisa dituntaskan di tahun 2020 


\section{DAFTAR PUSTAKA}

Arikunto, Suharsimi. Prosedur Penelitian, Suatu Pendekatan Praktek edisi revisi V. Jakarta , November 2002.

Ali Mufiz, Drs, MPA, Pengantar Administrasi Negara, Karunika Jakarta , Universitas Terbuka 1985

Dadang Solihin, Drs, MA, Makalah Lokakarya Model Indeks Pemerintahan Indikator Governance dan Penerapannya dalam Mewujudkan Demokratisasi di Indonesia, Bappeda Jawa Barat Bandung, 17 April 2007.

Hessel Nogi S.Tangkilisan, Drs. M.Si, Kebijakan Publik yang Membumi, Lukman Offset YPAPI, Yogyakarta, 2003.

Arie Sulandro, Bahan Paparan Pemetaan Good Governance, Peningkatan Pelayanan Pulik dan Penanggulangan KKN di Propinsi Kepulauan , BPKP Pusat Jakarta-www.kepriprov.go.id, 14 November 2006.

Solichin Abdul Wahab, Drs MA, Analisis Kebijakan Dari Formulasi Ke Implementasi Kebijaksanaan Negara, Bumi Aksara,Jakarta, 1991

Moeloeng , Lexi J., Metodologi Penelitian Kualitatif, Bandung: PT Rosdakarya,2008,

Nawawi, Hadari,Metode Penelitian Ilmiah, Jakarta:Rineka Cipta,1994

Wayne Parson, Public Policy, Pengantar Teori dan Praktek Analisis Kebijakan, Kencana Prenada Media Group,Jakarta, 2006

Edi,Suharto, Makalah Pembangunan Kesejahteraan Sosial dalam Pusaran Desentralisasi dan Good Governance, Balai Besar Pendidikan dan Pelatihan Kesejahteraan Sosial (BBPPKS) Banjarmasin, 21 Maret 2006.

Sondang P.Siagian, Filsafat Administrasi, Gunung Agung ,Jakarta, 1995

Guy Beneviste, Birokrasi, Rajawali Pers, Jakarta, 1994

Koenjaraningrat, Metode-metode Penelitia Masyarakat, Gramedia, Jakarta, 1980.

The Liang Gie, Keadilan sebagai Landasan bagi Administrasi Pemerintahan dalam Negara Republik Indonesia, Liberty, Yogyakarta, 1993.

Pariara Westra,Drs,SH, Ensiklopedia Administrasi, Gunung Agung, Jakarta, 1981. 
Jurnal SOSIO DIALEKTIKA 6 (1) (2021)

P-ISSN: 2540.8941 e-ISSN: 2623.2944

sosiodialektika@unwahas.ac.id
Gambaran Program Kotaku

(Kota Tanpa Kumuh )

Kota Semarang Tahun 2019

(Studi Evaluasi Kebijakan)

Fandy Tjiptono, Manajemen jasa, Andi Offset, Yogyakarta, 1996.

Undang-undang (UU) No. 1 Tahun 2011 tentang Perumahan dan Kawasan Permukiman

Undang-Undang RI Nomer 6 Tahun 2014 tentang Desa

PP Nomor 43 Tahun 2014 tentang Peraturan Pelaksanaan UU Nomor 6 Tahun 2014

PP Nomer 14 tahun 2016

PERMENPUPR 14 tahun 2018

Dokumen RPLP dan RP2KP 2019

SK Kumuh Kota Semarang 2019

Acceselaration Strategy Kota Semarang 2019

RPJMD Kota Semarang

SK No 050/801/ 2014, Walikota Semarang Tahun 2014 